\title{
MOTIVATIONAL READINESS OF STUDENTS TO WORK WITH CONVICTED PRISONERS IN UKRAINE
}

\author{
Nataliia Klishevich \\ Borys Grinchenko Kyiv University, Kyiv, Ukraine \\ Vadym Sulitskyi \\ Borys Grinchenko Kyiv University, Kyiv, Ukraine
}

\begin{abstract}
The ongoing reform of Ukrainian penitentiary service places high demands on the moral and psychological qualities of correctional staff facilities. Particular attention is paid to the issues of motivation and motivational readiness of employees in difficult, special conditions with clients of the correctional system. Therefore, the aim of our study was to establish and analyze how much motivational readiness has been formed among cadets and students to work with prisoners in prison, to identify whether there are patterns that affect the formation of positive or negative motivation in the process of professional training. In our work, we used the following methods: analysis of statistical data of personnel of the State Penitentiary Service of Ukraine, which are in the public domain; questionnaires; interview. We identified four main motives that positively affect the choice of work in a correctional facility: social security; fight against crime; retirement; work with people. At the same time, there are factors that form a negative motivation for employees, namely: working and resting conditions; lack of visible work results; negative impact of the criminal environment and subculture, which contribute to psycho-emotional burnout and professional deformation of the staff of correctional facilities. The results allow revising the curriculum for training of personnel for working with clients of the correctional system; reveals the existing problems of employees of the State Penitentiary Service of Ukraine; have a positive impact on reducing the number of layoffs among staff; helps to draw attention to professional, moral and ethical qualities when accepting candidates for work in correctional facilities.
\end{abstract}

Keywords: cadet, clients of the correctional system, correctional facilities, motivation, motivational readiness, professional training, student.

\section{Introduction}

Changes in the penitentiary service of Ukraine aimed at further humanizing the process of execution and serving of sentences. In the process of reforming the State Penitentiary Service of Ukraine, the requirements for employees of penal institutions are increasing (Naïzzhala, 2017). Particular attention is paid to moral and psychological qualities (Duka, 2014). This is due to specific working conditions that require positive motivation for workers to work (Maksimenko, 2018). 
Therefore, the upcoming changes require not only the introduction of modern technologies of socio-pedagogical and psychological work with prisoners, but also make essential adjustments in staff training aimed at developing specific competencies, and most importantly, taking into account, if the employment of motivational readiness to work with the prisoners in the constant negative influence of the criminal subculture of the community.

In Ukraine, there are quite a large number of articles, reflecting the impact of motivational readiness of students to various professional activities. Features of activity of criminal Executive service of Ukraine, issues of professional and special training of specialists, problems of motivational readiness of students to work in correctional colonies and remand centers studied by O. Duka, T. Kushnirova, M. Suprun and others.

In the literature on preparing staff for work in places of deprivation of liberty, special attention is paid to the motivational component in the professional readiness of students. Currently, there are a number of approaches to solving this issue. The first, is of the view that the motivational readiness of the cadets / students should be formed while teaching them in special schools (Duka, 2014; Kushnirova, 2014). Second - that higher education can be obtained in any University, but before applying for a job, everyone gets a position, should receive specific initial training (Suprun, 2016; Naïzzhala, 2017; Maksimenko, 2018). Then, the authors diverge on the timing of such training. But, in General, they range from two months to one year. The third involves a trial period and supervisor for a candidate to work in prisons, with the aim of establishing the true motive of choice of work (Makarenko \& Kozhushko, 2018).

Each of these approaches has a right to exist. With regard to the formation of motivational readiness of students, the first approach seems more efficient. Therefore, the aim of our study was to establish and analyze how much motivational readiness has been formed among cadets and students to work with prisoners in prison, to identify whether there are patterns that affect the formation of positive or negative motivation in the process of professional training.

The data obtained by us can be used in the preparation of curricula and programs for the training of employees of penal institutions, during the professional selection for work in penal institutions, and the organization and conduct of classes for professional and special training of personnel.

\section{Methods}

This study was conducted in the period from January 2019 to June 2019. One of the methods of our research was the analysis and synthesis of statistical data on the issue of staffing in the institutions for execution of punishments, which are 
publicly available on the website of the State Criminal-Executive service of Ukraine.

During the research we used methods of questioning and extended individual interviews.

The questionnaire consisted of four blocks of questions. The first gives information about the interest examined for their chosen profession, the second defines the relationship of the respondents to convicted prisoners with whom they will work; the third answers the question: "Why the student goes to work in a penal institution?"; the fourth reveals the expectations of the respondents from this activity in the future.

In addition to the questionnaire we interviewed each of the participants. The duration of interviews was from 30 to 50 minutes. We asked them to answer the same questions, only in a more extended form, asking them clarifying questions, which allowed us to get more information about the motives of employment in institutions for execution of punishments. Additional questions were personalized on the basis of the responses received during the survey.

To obtain more reliable data, the study was confidential. Each participant gave voluntary consent to participate in the survey and the interview. When conducting interviews, we adhered to ethical rules. If someone didn't want to answer some of the questions, we didn't push it. One of the main conditions of the study - voluntary participation.

During the research, we took into account the historically formed sociocultural features of our state. The questionnaire was prepared in two languages: Ukrainian and Russian, and the interviews were conducted in the language chosen by the subjects. It is possible to avoid misunderstanding and misinterpretation of questions and answers.

\section{Study participants}

The study authors turned to potential candidates to work in the structures of the State Criminal-Executive service of Ukraine. We asked them to answer a series of questions that helped to get an idea about the open and hidden motivations of employment in establishments of execution of punishments.

The study involved 90 people, of which were formed three groups of 30 people each. The first students of specialized higher educational institutions; the second for students who wish to work in the prison system, the third employees of institutions of execution of punishments. Socio demographic characteristics who participated in the study are given in table 1. 
Table 1 Socio-demographic characteristics of students and cadets who participated in the survey

\begin{tabular}{|l|c|c|}
\hline Socio-demographic characteristics. & Students & Cadets \\
\hline Number of participants & 30 & 30 \\
\hline The average age & 22,8 & 22,6 \\
\hline Gender: & 12 & 16 \\
$\quad$ men's & 18 & 14 \\
$\quad$ women's & $4-5$ course Institute & $4-5$ course Institute \\
\hline Education & 28 & 27 \\
\hline Marital status: & 2 & 3 \\
$\quad$ idle & 25 & 12 \\
$\quad$ married & 5 & 18 \\
\hline Place of residence: & & \\
the city & & \\
the countryside &
\end{tabular}

As we can see, the groups on the number of participants and the main sociodemographic characteristics are equal. Most of the students lived in rural areas. This is due to the fact, that $40 \%$ of prisons are located outside cities.

For comparison, the motive for the employment in prisons of students / cadets with the motives of existing employees, we conducted the same research with students of training courses. Socio-demographic characteristics of this group are presented in table 2.

Table 2 Socio-demographic characteristics of employees of institutions of execution of punishments, took part in the survey

\begin{tabular}{|l|c|}
\hline Socio-demographic indicators & Employees \\
\hline Number of participants & 30 \\
\hline The average age of & 34,3 \\
\hline Gender: & 22 \\
men's & 8 \\
women's & \\
\hline Education: & 30 \\
$\quad$ higher & 12 \\
\hline Marital status: & 18 \\
$\quad$ idle & \\
married & 19 \\
\hline Place of residence: & 11 \\
the city & 1 \\
the countryside & 6 \\
\hline Work experience: & 11 \\
up to 1 year & 12 \\
up to 3 years & \\
to 5 years & \\
more than 5 years & \\
\hline
\end{tabular}




\section{Data collection and analysis}

By analyzing information on staffing of the State criminal-Executive service of Ukraine, which is publicly available on departmental websites, we had identified these trends: $60 \%$ of the students enrolled in the departmental educational institutions, after their graduation, is not going to work in institutions for the execution of sentences; for the year change of the personnel of penal colonies and remand centers is $30 \%-50 \%$ of the total number of employees; average is not the provision of work posts in the penal institutions is from $10 \%$ to $40 \%$ of the personnel; about $15 \%$ personnel dismissed from work in the first year after appointment; every year from $1.3 \%$ to $2.5 \%$ of employees are subject to criminal prosecution for abuse of authority and abuse of power; for all time of Ukrainian independence, the prison service is in a constant state of sluggish reform, negatively affecting morale of staff and is one of the causes of turnover; about $40 \%$ of employees have no special education, which negatively affects the quality of work on the correction and resocialization of prisoners; the main reason of layoffs of personnel is the inability to resist negative influence of a specific medium prisoners, their criminal customs and traditions; the reduction of specialized higher education institutions leads to a shortage of specialists in the field of penitentiary pedagogy and psychology, criminal-Executive law; the average salary of an employee of the institution for execution of punishments in 1.5 times less than the wages of any other law enforcement Agency.

\section{Results}

1. Interest in the chosen profession. Of the 30 surveyed employees only three people have chosen their profession consciously. 24 people working in the institutions for the execution of the punishment factor in the choice of occupation identified "the vital coincidence". Of 30 people, only five people graduated from a special school, and the rest came after graduation, in humanitarian and technical institutes. three people really wanted to be in the military, to have the title and carry straps.

Fourteen of the surveyed students "followed the example of their parents", but dreaming of another profession; seven people indicated that this was the only way for them to obtain a higher education; six people referred to the circumstances of life and only four cadets chosen profession independently.

To the question: "What factor played a decisive role in choosing a profession?", students answered this way: 5 people have chosen the profession on the recommendation of relatives; 13 man - I really want to dedicate his life to fighting crime; 12 students admitted that they dream of wearing epaulets and to be officers. 
Next to students of the question was "Do you plan after graduation to work in the specialty?" 21 cadets answered that it is not going to connect the life with work in institutions for execution of punishments. Six people will be working with prisoners in places of deprivation of liberty, but at the first opportunity change the place of work. Three persons fully decided to devote his life to working in prisons.

On this question students answered in this way: 15 people identified a desire to devote their activity to work with offenders; 15 people - really want to devote my life to working in the prison service, but do not exclude the possibility of dismissal from the service if their expectations do not justify the current reality.

For employees of institutions of execution of punishments, we rephrased the question: "Do you plan to continue to work in the penitentiary?" We received the following results: out of 30 surveyed employees only 23 people are going to retirement to work with prisoners in places of deprivation of liberty; 7 people, continuing to work in correctional colonies, in parallel, searching for a new job that is less related to neuro-psychological load.

2. The convicted persons. For students typical were such responses: positive, good, we are all human, they need help, work require any specific knowledge; you have to be careful. Six people pointed to the possibility of professional deformation and emotional burnout.

Students were less optimistic in their answers: it is very hard work; the convicts cannot be corrected; it is important to know the criminal subculture and to possess other specific knowledge that reveal the psychological characteristics of different offenders; everyone has the right to a second chance. Four people see in this activity the meaning of life.

The staff were more categorical in their appraisal judgments Among answer prevailed: hard, difficult, thankless job, exhausting, dangerous. Only two responses were positive: we help them get better; they have the right to hope for the best.

3. The definition of the motives for working in institutions for execution of punishments. The main motive when applying for work in penitentiary institutions is the willingness to help people who are in conflict with the law (54 respondents). Second most important is the feeling of self-protection in social and legal terms (20 respondents). Third - the opportunity to make their personal contribution to the fight against crime (9 respondents). Fourth - the presence of social guarantees from the state as they personally and their family members (5 respondents). Fifth - the ability to get free higher education (4 respondents).

4. Expectations of respondents from working in penal institutions. The most common expectations were: social security; career growth; stable wages and additional payments; guaranteed vacation; paid sick leaves; an opportunity to receive higher education; earlier retirement compared to other professions; availability of social security for a member of the employee's families. 
SOCIETY. INTEGRATION. EDUCATION

Proceedings of the International Scientific Conference. Volume I, May $22^{\text {th }}-23^{\text {th }}, 2020.424-431$

\section{Discussion}

The decisive factor in the choice of profession is not the desire and motivation willingness to work with prisoners, and the influence of parents and close relatives during the interviews, we have found that $70 \%$ of respondents mediocre in school; 84\% of the students receipt of departmental higher educational establishment was seen as the only option of higher education; $17 \%$ of students and $12 \%$ of the students in adolescence are faced with physical and moral violence towards themselves; $34 \%$ dismissive put to physical labor; 9 employees chose to work at the prison as nowhere else are unable to get a job, and 11 explained the employment in the colony as "a confluence of unfavorable circumstances."

Significantly different answers in the questionnaire from the responses received during the interview, related to the convicted. 79 of respondents have a negative attitude towards people who are serving sentences. They do not believe in the possibility of their correction, I think "dregs of society", hardened criminals. 11 respondent's number of students believe that the convict may reform and become a different person, that humanism and kindness is most important in life.

During the interviews, we established the motives that respondents had indicated in the questionnaire: having power over other people; full state support; fast career progression; the opportunity to improve their material and financial status; additional possibilities.

In addition to answering the questions, respondents talked about the knowledge needed for work in the prison service, increase their motivational readiness to work with the prisoners.

For us, the results proved to be predictable: students rated their knowledge level on 9 points; staff -7 , students -4 . 73 people interviewed categories indicated that possess special knowledge acquired in the course of attending special trainings and seminars. The respondents said that they read a lot of literature independently. At the same time, officials point to the lack of knowledge in the field of clinical psychology and health; a lack of methodical recommendations on the organization and conduct of individual sociopedagogical and psychological activities among prisoners. 100\% indicated a need for additional professional knowledge that would like to receive in the form of information-based learning $-27 \%$ and $73 \%$ of training sessions. It is the presence of special knowledge, according to the staff, play an important role in motivational readiness to work with the prisoners.

In order to avoid in our study of the "errors of the survivors", we were asked to answer the question retired from the institution for execution of punishments of the employees: "What was the main motive in the decision to retire from the service?" The answers were as follows: long working hours; authoritarian 
leadership; most of neuropsychological stress; fear of contracting tuberculosis or AIDS virus; found a more relaxed work; continuous reorganization, which "kills" the belief in a better tomorrow; a lack of understanding from the team; the presence of conflict situations with management or prisoners; the disappointment, the discrepancy between the expected and the real situation in the prison service.

\section{Conclusion}

As we can see from our research, the formation of motivational readiness occurs at the stages of career choice and learning in higher education, and finally formed in the first three years of service in institutions for execution of punishments. The motivation differs from idealistic students, for example, "fight against crime", to commonly consumer employees: "early to retire". Motives do not always correspond to the true expectations from the activity, and respondents tend to hide their goals and expectations from the profession.

Thus, in the future, it is advisable to conduct research to identify true and false motives for candidates to work in institutions; assessment of the emergence of "risk behavior" of employees; system for prediction of success in professional activity.

\section{References}

Naïzzhala, M. (2017). Zarubizhnij dosvid profesijnoï pidgotovki pracivnikiv Derzhavnoï kriminal'no-vikonavchoï sluzhbi. Aktual'ni problemi prav ljudini, jaka perebuvae $v$ konflikti iz zakonom, kriz' prizmu pravovih reform, 171-174.

Duka, O. (2014). Sushhnost' i struktura professional'noj kompetentnosti budushhih oficerov Gosudarstvennoj ugolovno-ispolnitel'noj sluzhby Ukrainy. Nauchnyj vestnik Instituta Gosudarstvennoj ugolovno-ispolnitel'noj sluzhby, 1(14), 102-108.

Maksimova, N. (2018). Jemocional'noe vygoranie sotrudnikov Gosudarstvennoj ugolovnoispolnitel'noj sluzhby Ukrainy kak osnovnaja prichina tekuchesti kadrov: Aktual'nye problemy zashhity prav cheloveka, kotorye nahodjatsja $v$ konflikte s zakonom, 278-281.

Kushnirova, T. (2014). Professional'no-psihologicheskaja podgotovka sotrudnikov Gosudarstvennoj ugolovno-ispolnitel'noj sluzhby Ukrainy po nejtralizacii negativnyh psihicheskih sostojanij. Kyiv: «MP Lesja».

Suprun, N. (2016). Samovospitanie lichnosti budushhih specialistov v oblasti penitenciarii. Nauchnyj vestnik Instituta Gosudarstvennoj ugolovno-ispolnitel'noj sluzhby, 1(11), 109-121.

Makarenko, P., \& Kozhushko, A. (2018). Osoblivosti emocijnoï sferi pracivnikiv Derzhavnoï kriminal'no-vikonavchoï sluzhbi v umovah profesijnoï dijal'nosti. Aktual'nye problemy zashhity prav cheloveka, kotorye nahodjatsja v konflikte s zakonom, 282-285. 